\title{
TOWARD A MORE COMPREHENSIVE MODEL OF FIRMS' HUMAN CAPITAL RENTS
}

\author{
CLINT CHADWICK \\ University of Kansas
}

\begin{abstract}
Strategic human capital research has recently expanded to encompass other types of labor market frictions in addition to those posed by firm-specific human capital. Labor market frictions inhibit trade in human capital, allowing firms that are idiosyncratically advantaged with respect to a particular friction to appropriate human capital rents. Adding to this nascent conversation, I describe how idiosyncratic firm resources and capabilities enable firms to garner human capital rents. By explicitly distinguishing between value creation and value capture, which together drive firm-level human capital rents, this article's theoretical framework uncovers overlooked circumstances where firms' pursuit of human capital rents differ in important ways. I discuss theoretic propositions and implications to guide future research.
\end{abstract}

The strategic human capital (SHC) literature is currently experiencing an explosion of interest. The general question that has animated this research is "How can firms accrue human capital rents for themselves?" since the default outcome in labor markets characterized by perfect competition is that human capital rents go to workers. For years, scholars in this rapidly growing stream of research fixated on the distinction, handed down from labor economics, between firm-specific and general human copital. Firm specificity simultaneously solves two distinct problems related to firms' human capital rents: (1) the need to drive up the value that human copital creates and (2) the need for isolating mechanisms that prevent workers from selling their services to the highest bidding firm and, thus, appropriating that created value for themselves. However, as in other parts of the strategy field, SHC theorists have begun to distinguish more explicitly between these two processes (e.g., Coff, 1999). The former (driving up created value) can be described as value creation, while the latter (isolating mechanisms issues) can be described as a part of value capture on behalf of the firm. Human capital firm specificity confounds these two issues. Moreover, the emphasis on firm specificity has tended to limit SHC scholars' attention to a specific circumstance

This paper benefited from the comments of Jay Barney, Ben Campbell, David Kryscynski, Janice Molloy, Wafa Orman, participants at the 2013 University of Utah Human Capital Conference, former AMR associate editor Vilmos Misangyi, and three anonymous reviewers. I thank them for their immensely helpful contributions. out of a broader class of conditions-labor market frictions-where human capital can drive firmlevel rents (cf. Campbell, Coff, \& Kryscynski, 2012).

More subtly, applying human capital theory to firm rents has tended to fix SHC scholars' attention on the characteristics of human capital itself, rather than on the characteristics of firms. In contrast, the fundamental argument in this article is that for firms to garner human capital rents, they must leverage unique firm-level capabilities and resources vis-à-vis either human capital value creation or human capital value capture. In other words, the firm specificity that matters for firms' human capital rents resides not in human capital itself but in firms' human copital-related resources and capabilities. ${ }^{1}$ Accordingly, in this article I explicitly take a firm point of view on human capital rents. Nevertheless, my reasoning is informed by interactions between individual workers and firms.

It is important to pause here to consider how human capital differs from other types of firm resources. Human capital poses unique challenges (or management dilemmas, as Coff [1997] called them) compared to other types of resources. These challenges make firms' pursuit of human capital rents distinctively difficult and different from firms' pursuit of rents through other types of resources. While a full review of these challenges lies outside of the scope of this article, I will briefly describe two of these challenges that are most

\footnotetext{
${ }^{1}$ To avoid confusion with firm-specific human capital, I typically use the term idiosyncratic to refer to resources and capabilities that are unique to firms.
} 
pertinent to this article: workers' free will and workers' perpetual ownership of their human capital. Free will denotes workers' cognitive and affective reactions to their conditions of work (Wright, Dunford, \& Snell, 2001). As Coff (1997) and others have noted (e.g., Chadwick \& Dabu, 2009), workers' thoughts and feelings have a direct impact on what they are willing to do and how hard they are willing to work - that is, on the value that their human capital creates. One implication of free will is that workers' utility functions encompass both financial and affective dimensions. Hence, relationships with firms are both labor economic exchanges and affective relationships (Baron \& Kreps, 1999), and firms must effectively manage both aspects of employment to accrue human capital rents.

The affective side of employment relationships makes the management of human capital more varied, less predictable, and therefore less readily leveraged for rents by firms than is the case for other types of firm resources. For example, it is not uncommon for workers to quit their jobs because of dissatisfaction with their immediate supervisor, even when this hurts these workers' economic interests (Molloy \& Barney, 2015). Other facets of employment relationships that have significant affective components include how workers identify with their firms, the intrinsic satisfaction provided for diverse types of workers by different types of work, workers' inclination to give discretionary effort on the job, and workers' reactions to job conditions. These topics, of course, have been extensively studied in such fields as organizational behavior, human resource management, industrial relations, and behavioral economics, although authors in these fields have seldom framed their interest in these topics around firms' human capital rents.

Additionally, a dilemma for firms that is posed by workers' perpetual ownership of their human capital is that they always retain the option to put their human capital to work for a competitor; the firm can never take ownership of a worker's human capital (Becker, 1964; Hart \& Moore, 1994). As one might put this point colloquially, human capital can only be rented by the firm; the firm can never purchase it. Consequently, when human capital rents occur, other things being equal, workers' perpetual ownership of their human capital gives them greater leverage to bargain for a portion of the rents that are thus created than is typical for parties that provide other types of resources to firms. Indeed, since workers' ownership of their human capital is perpetual, negotiating worker compensation is a perpetual (albeit intermittently perpetual) process as well. ${ }^{2}$

Both of these factors give workers greater bargaining power to extract a portion of the value that their human capital creates than is typical for the owners of other classes of firm resources, such as technology or physical capital. Additionally, free will creates variance and uncertainty in how much value a worker's human capital will generate. Consequently, for firms, garnering rents from human capital is complex, with abundant opportunities for failure, and is a significantly different endeavor than is pursuing rents from other types of resources.

While the evolving SHC research conversation has encompassed some of these salient points in various publications, we have been hampered in forming a more comprehensive story of firms' human capital rents by the SHC field's previous emphasis on firm specificity. Thus, in this article I will break from traditional, labor economicsbased human capital theory and use a combination of resource-based theory (RBT) and strategic factor market theorizing to describe where and how firms' idiosyncratic resources and capabilities drive human capital value creation and value capture. In doing so I will describe how human capital theory and RBT/strategic factor market theory are mismatched in fundamental yet frequently overlooked ways. Consequently, the perspective I propose here allows us to better see where we currently stand in SHC research and yields new understandings about where SHC research could go next.

\section{THE THEORETIC FOUNDATIONS OF HUMAN CAPITAL RENTS}

The essential question I consider in this article is "How does human capital generate rents for firms?" While the primary outcome of interest in this study is the human capital rents that accrue to firms, I will also make frequent reference to workers' human capital rents in the arguments that follow. In line with the majority of SHC

\footnotetext{
${ }^{2}$ Note, for instance, how frequently firms worry that their most valuable workers will be "poached" by competitors (Groysberg, 2012; Groysberg \& Abrahams, 2006), regardless of whether those workers' formal contracts are up for explicit renegotiation.
} 
scholars, I will address this question based on RBT descriptions of how firm-level economic rents occur in the context of strategic factor markets. Rents are the economic profit (profit in excess of opportunity costs) that accrue to a factor of production (which I hereafter call resources in this article). The emphasis in RBT is on a particular kind of rent, Ricardian rents. As I will describe in greater detail, such rents are determined by product market revenues generated by a resource in comparison to the resource's next best use. Ricardo emphasized that variations in the quality of a resource, combined with inherently fixed (inelastic) supply, can create rents as higherquality versions of the resource generate sustainably greater returns from customers for their owners (Chadwick \& Dabu, 2009). Conversely, lesser-quality versions of the same resource, which are valuable but in common supply, are likely to only "break even"-that is, the value that such resources generate for their owners over the opportunity cost of their next best use is small or nonexistent (Barney, 1991; Barney \& Wright, 1998). In short, resources generate more value when they lend desirable uniqueness to the products or services that are sold to customers.

RBT describes how such resources are traded on strategic factor markets. Strategic factor markets are markets on which resources that are inputs to firms' value creation processes can be bought and sold (cf. Barney, 1991). Whenever such resources are in demand, a strategic factor market will arise to supply it. When perfect competition prevails in a strategic factor market, supply and demand balance perfectly such that the value that a resource can generate is completely encapsulated in its factor market price. Consequently, no rents can accrue from the ownership of resources that are traded in perfectly competitive strategic factor markets.

The central tenet of RBT, of course, is that resources can become a source of persistent firm rents when a strategic factor market deviates from perfect competition. Perfect competition has a number of defining characteristics, including (1) perfectly available and accurate information about product quality and pricing, (2) costless transactions, (3) free exchange between parties in the market, (4) free movement of firms into and out of the market, and (5) participants that behave in their rational self-interest. Departures from each of these conditions may provide firms with opportunities to create rents through their resources and capabilities. For example, if a firm is able to execute factor market transactions at costs below the prevailing rate in the factor market, it can capture the difference in its resource acquisition costs as an extra margin, along with other potential advantages. The familiar value, rareness, inimitability, and nonsubstitutability (VRIN) criteria in RBT summarize conditions when strategic factor markets deviate from perfect competition. These deviations from perfect competition are commonly labeled in the strategy literature as market imperfections or frictions (I use "frictions" in this orticle).

With respect to rents, it is common for users of RBT to equate inelastic supply with rareness. More precisely, however, Ricardian rents in RBT are rooted in scarcity-that is, in inelasticities in the supply of a valuable resource on a strategic factor market (cf. Barney, 1991; Mackey, Molloy, \& Morris, 2014; Peteraf, 1993). This is a crucial distinction since it acknowledges that supply inelasticity either can be an inherent characteristic of a resource or can be created by market circumstances. In other words, scarcity (inelastic supply on a strategic factor market) drives Ricardian rents, whether or not the resource is inherently rare. Even temporary inelasticity in the supply of a resource can lead to firm rents if it is to the advantage of a particular firm. ${ }^{3}$

For example, gold is a commodity that has a supply that both grows very slowly and is largely inelastic. A firm that secured most of the world's gold supply for itself could have an opportunity to earn rents if it managed to do so in some way that allowed it to pay less than the going market price for gold (presumably by leveraging a friction in the market for gold). However, if a firm could "corner the market" in the short term on an inherently abundant and replaceable resource, such as wheat, it might also be able to gain Ricardian quasi-rents from this ability to leverage a factor market friction. In the short term, either type of supply inelasticity (scarcity), inherent or created, can yield rents to the owners of a resource. The common factor is firms' resources or capabilities that allow them to take advantage of factor market frictions. This is the essence of isolating mechanisms: a firm's

\footnotetext{
${ }^{3}$ Properly speaking, when supply inelasticities are fixed in the short run but cannot be maintained in the long run, as is likely with most human capital, they lead to Ricardian quasi-rents.
} 
ability to leverage market frictions in ways that shield it from competition in the factor market in an idiosyncratic fashion. Accordingly, market frictions that impact all firms in a factor market in a similar way do not create rents.

Likewise, in human capital, high levels of skill in medical specialties are not easily acquired in the short term, a friction in the strategic factor market for human capital. (Throughout this article I use "the labor market" as a shorthand term for the strategic factor market for human capital.) If the demand for a particular medical specialty (say, dermatology) were to suddenly increase, firms that had claim to that human capital could capture Ricardian quasi-rents until an increased supply of dermatologists eventually began to enter the labor market, even though dermatology skills are not an inherently rare form of human capital.

\section{Conceptualizing Firms' Human Capital Rents}

Indeed, as with Ricardian rents from other types of resources, firms' human capital rents stem from cross-firm differences in the quality of human capital combined with inelasticities in human capital supply on the labor market (cf. Chadwick \& Dabu, 2009). Barney (1991), Peteraf (1993), and other RBT scholars have observed that resources such as human capital create firm rents when the value that they generate from customers lies above the firm's cost of acquiring and retaining those resources. Thus, when applied to human capital, RBT/strategic factor market theory posits that firms' human capital rents are driven by two distinct but related issues: (1) characteristics that drive up the value that human capital creates and (2) characteristics that drive down the cost of human capital to the firm. Together, these two processes open up a gap between value and costs that comprise firms' human capital rents (Molloy \& Borney, 2015).

Figure 1 gives a simple illustration of this conceptual argument. In this figure the value that human capital generates from customers that lies above their workers' next best use of their human capital (opportunity costs) is split between the firm and its workers, with the portion of created value that goes to the firm (net of the firm's cost of human capital) comprising the firm's human capital rents. In the figure the value that workers' human capital generates from customers is labeled "value in use." Value in use harks back to
Penrose's (1995) oft-cited point that resources are not valuable in themselves but, rather, for the "services" they can render to firms and to customers. Human capital value in use is partially idiosyncratic to firms, since it is linked both to human capital characteristics that are applicable across firms and to complementarities between human capital and idiosyncratic firm conditions, such as management practices, technologies, methods of production, and coworkers. Hence, the value that a specific worker's human capital generates can vary from firm to firm, even if the worker's human capital is not itself tied to a particular firm. Correspondingly, human capital potential value in use also has a partially idiosyncratic nature. Potential value in use is the maximum possible value in use that workers' human capital can generate for a particular firm. The difference between potential value in use and actual human capital value in use represents as yet unrealized opportunities to generate increased value in use.

Of course, workers as well as firms reap some of the value that their human capital creates. The difference between the financial compensation that the firm pays to workers for use of their human capital and the compensation that workers would receive from their human capital's next best uses is the human capital rents that accrue to workers. ${ }^{4}$ As the terminology suggests, if workers' compensation from a firm falls below that from their next best opportunities, they will be motivated to take the latter and will do so in a perfectly competitive labor market. It is important to acknowledge here the impact of workers' affective relationships to their firms. As has been well documented in a variety of research streams, workers' compensation from a firm is both financial and nonfinancial. Recall that Figure 1 depicts human capital rents from a firm's point of view, so the value of nonfinancial compensation is not explicitly included in the depiction of firm rents in

\footnotetext{
${ }^{4}$ To some degree, scholars in the strategy literature have tended to describe only the economic profits that accrue to owners of the firm as rents. However, the stakeholder view of the firm suggests that economic profits that accrue to human capital-providing stakeholders (i.e., workers) are also rents (cf. Coff, 2010). Since ownership of human capital cannot be transferred from workers to firms, a view of workers as capable of accruing rents is theoretically consistent: workers are not just factors of production but are the providers of a key resource to the firm, just as capital providers are. I thank Ben Campbell for clarifying this point.
} 
FIGURE 1

\section{Theoretic Depiction of Firms' Human Capital Rents}

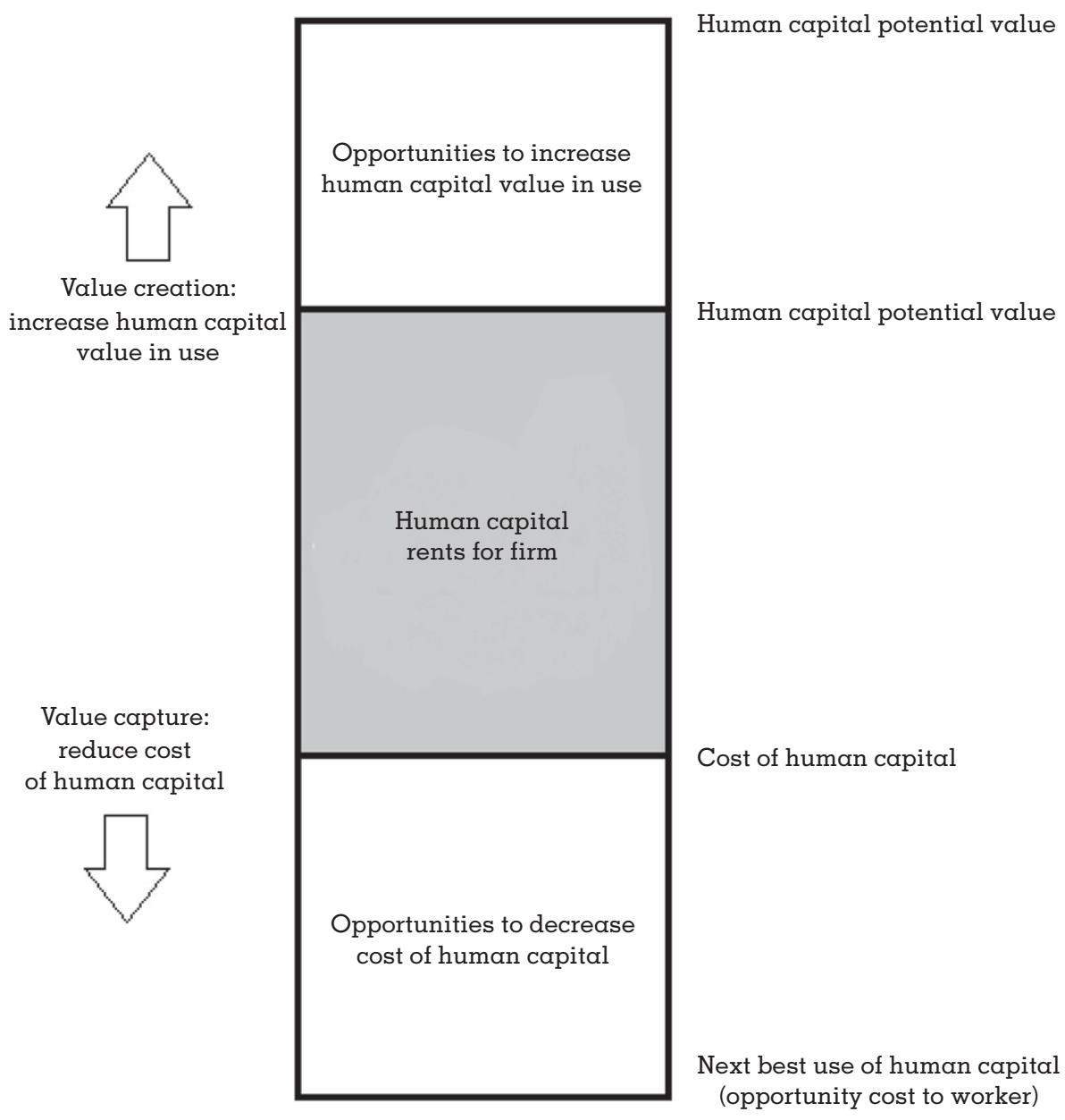

this figure. However, I will return to this topic below.

In a way that is analogous to human capital value in use, the costs of workers' human capital to the firm encompass both costs for that human capital that generalize across firms on the labor market (sometimes denoted in SHC research as human capital "exchange value") and the costs of acquiring and retaining that human capital that are more particular to the firm (cf. Chadwick \& Dabu, 2009), such as financial compensation to workers for firm-specific working conditions. Note that both of those types of human capital costs are specific to individual workers and their working conditions. However, the costs to the firm for workers' human capital also include the administrative costs of managing firms' HRM systems, cultures, and so forth that generalize across larger groups of workers, perhaps even applying to the firm's workforce as a whole. As I describe below, both worker-specific human capital costs and these more generalized human capital administrative costs present the firm with opportunities to make reductions in human capital costs that increase the human capital rents the firm accrues from its workers.

Indeed, as Figure 1 implies, firms can generate greater human capital rents from workers' human capital by broadening the gap between the value in use of workers' human capital and the cost that the firm pays for that human capital. One way to do this is by raising human capital's value in use closer to its potential value (cf. Kraaijenbrink, 2011) through skillful management, such as through a training program or by creating complementarities with coworkers within the firm. In this article I label the process of boosting human capital's value in use closer to its potential value 
human capital value creation. The other way for firms to increase the rents that they garner from their workers' human capital is to reduce the costs they pay to acquire and retain human capital, such as by striking good bargains with workers over wages or by reducing the administrative costs of managing human capital. This process is human capital value capture for firms.

While value capture has frequently been viewed in the extant SHC literature as synonymous with human capital value appropriation (stemming from reducing workers' financial compensation; cf. Coff, 2010), value capture, as I use the term in this article, encompasses both value appropriation and human capital administrative efficiencies. As I describe below, effective management of either cost can reduce the firm's cost of acquiring and retaining workers' human capital. Human capital value appropriation requires firms to leverage idiosyncratic advantages with respect to labor market frictions, such as offering an attractive organizational culture that serves as meaningful and unique nonfinancial compensation for workers. When this occurs, those labor market frictions become isolating mechanisms that allow the firm to appropriate some of the value that workers' human capital creates. Administrative efficiencies, too, can drive down the firm's cost of human capital, thus expanding human capital rents to the degree that these efficiencies reflect idiosyncratic firm capabilities rather than innovations in effectively administering human copital that are easily imitated by competitors.

As depicted in Figure 1, the firm increases the human capital rents it garners from its workers by boosting the value in use of their human capital and/or by pushing down the cost of these workers' human capital to the firm (for an early statement of this argument, see Barney \& Wright, 1998). The relationship between the outcomes of these two related processes determines the human capital rents that the firm reaps from its workers. For instance, if a firm adopts an efficiency wage and raises workers' wages, it can still increase the human capital rents that it reaps from workers if the workers increase their discretionary effort on the job such that the value generated by their greater productivity exceeds the cost of the wage increase.

Furthermore, the two processes that determine value in use and the cost of human capital are dynamic. Consider, for example, a worker who has demonstrated greater value in use than the cost that her employer is paying for her human capital. Other things being equal, because workers retain ownership of their human capital, this worker is in a position to bargain for a higher wage than was negotiated before the employment relationship began, thus potentially shrinking the rents that her firm captures from her human capital. Conversely, an employer may renegotiate to lower a worker's wage or to terminate a worker's employment when the value in use of that worker's human capital falls below the cost of that worker's human capital to the firm.

\section{The Problematic Link with Firm Specificity}

Let us now juxtopose the RBT perspective with human capital theory as it has been employed in SHC research. Along with RBT/strategic factor markets theory, the majority of SHC work to date has also been anchored in the labor economic distinction between general (or portable) human capital and firm-specific human capital (e.g., Hatch \& Dyer, 2004; Kor \& Leblebici, 2005; Mayer, Somaya, \& Williamson, 2012; Wang \& Barney, 2006; Wang, $\mathrm{He}$ \& Mahoney, 2009). Becker $(1962,1964)$ and other labor economists originally developed firmspecific human capital arguments to explain variance in individual workers' wages. Consequently, applying firm specificity to explain firm-level human capital rents has some shortcomings that have hitherto been largely overlooked in SHC research.

The common firm specificity argument advanced by SHC researchers is that firm-specific human capital con drive firm rents because it is not tradable on the labor market. Thus, firmspecific human capital is an appealing match to RBT descriptions of strategic factor market frictions and rents because there is, by definition, no factor market at all for firm-specific human capital. In other words, firm-specific human capital's nontradability can be an isolating mechanism that allows firms to capture human capital rents by driving the cost of human capital down below its value in use. Nontradability is also a mechanism that may increase human capital value in use by perpetuating human capital scarcity. Therefore, firm specificity seems to be the epitome of RBT/strategic factor market logic as applied to human capital.

Yet human capital theory is a mismatch with RBT in important ways that have begun to capture 
greater attention from SHC scholars. Perhaps the most significant recent work that points out these mismatches is by Campbell et al. (2012), who suggest that SHC researchers have lost sight of the central phenomenon that drives human capital rent appropriation: labor market frictions. Consider, for instance, that the distinction between firm-specific and general human capital, as commonly applied by SHC scholars to firmlevel rents, encompasses the implicit assumption that the labor market for general human capital is perfectly competitive. From this point of view, then, the only meaningful inhibition to trade in human copital is firm specificity. Thus, firm specificity is the condition that allows firms to capture human capital rents that would otherwise go to workers.

However, as Campbell et al. (2012) propose, firm specificity is only one example (albeit a notable one) of labor market frictions. The authors suggest that the SHC field's preoccupation with firm specificity has caused it to overlook these other labor market frictions (cf. Wright \& McMahan, 2011). Indeed, the labor market is a strategic factor market where departures from perfect competition are both frequent and diverse, giving rise to a variety of frictions (in addition to firm specificity) that offer firms opportunities to capture human capital rents. As Campbell et al. (2012) suggest, these frictions can be of two types: (1) frictions that prevent workers from putting their human capital on the market (supply-side frictions) and (2) frictions that prevent firms from trading in the labor market (demand-side frictions). Moreover, Campbell et al. also outline circumstances where human capital is unlikely to lead to firm rents, such as when demand-side and supply-side labor market frictions are both weak. Thus, the authors demonstrate how the predominant firm specificity orientation in $\mathrm{SHC}$ research is incomplete with respect to value capture.

Additionally, I contend that much of the firmspecific skill or knowledge possessed by employees, such as understanding how to use the photocopier, knowing whom to talk to about reimbursable expenses, and following safety protocols for proprietary equipment, arguably concerns simple matters in employees' daily work and is therefore unlikely to generate human capital rents either because it is easily acquired or because it is peripheral to the firm's value creation processes. For either reason-easy acquisition or trivial value in use-the firm-specific human capital that can drive human capital rents for firms may be quite rare indeed. Moreover, such human capital is a small slice of the total human capital that firms put to use each day. Thus, firm specificity is likely to be only a part of the firmlevel human capital rents story.

Perhaps more important, broadening the focus of SHC research from human capital firm specificity to labor market frictions shifts our theoretic attention from characteristics of human capital itself to the functioning of the labor market, which is a closer conceptual match to RBT. From the RBT perspective, it is possible for firms to accrue human capital rents from many types of human capital as long as labor market frictions favor the firm idiosyncratically. This, in turn, points our attention toward firms' unique resources and capabilities. Moreover, value capture is only half of the human capital rents story, along with value creation, a point that is obscured in the case of human capital firm specificity, since it confounds value creation and value capture.

\section{HOW FIRMS ACCRUE HUMAN CAPITAL RENTS}

Consequently, a way to uncover a broader set of circumstances where human capital creates rents for firms is to explicitly distinguish between these two related but distinct processes and to describe how firm-level factors influence each of them in turn. Figure 2 depicts how key characteristics of human capital and firms' idiosyncratic human capital-related capabilities and resources together drive firms' human capital rents.

As I discussed in regard to the relationships portrayed in Figure 1, the difference between human capital value in use and the cost of human capital comprises firms' human capital rents. Thus, Figure 2 depicts a negative relationship at the firm level between the cost of human capital and firms' human capital rents and a positive relationship between human copital value in use and firms' human capital rents. Of course, the effects that the various constructs on the left side of Figure 2 have on firms' human capital rents in any particular circumstance vary with their relative strengths. Nevertheless, I can posit some general causal relationships among these constructs. On the one hand, as Figure 2 depicts, inherently scarce human capital and idiosyncratic firm complementarities increase human capital value in use. On the other hand, inherently scarce human capital, human capital administrative cost 
FIGURE 2

\section{Causal Map of Key Determinants of Firms' Human Capital Rents}

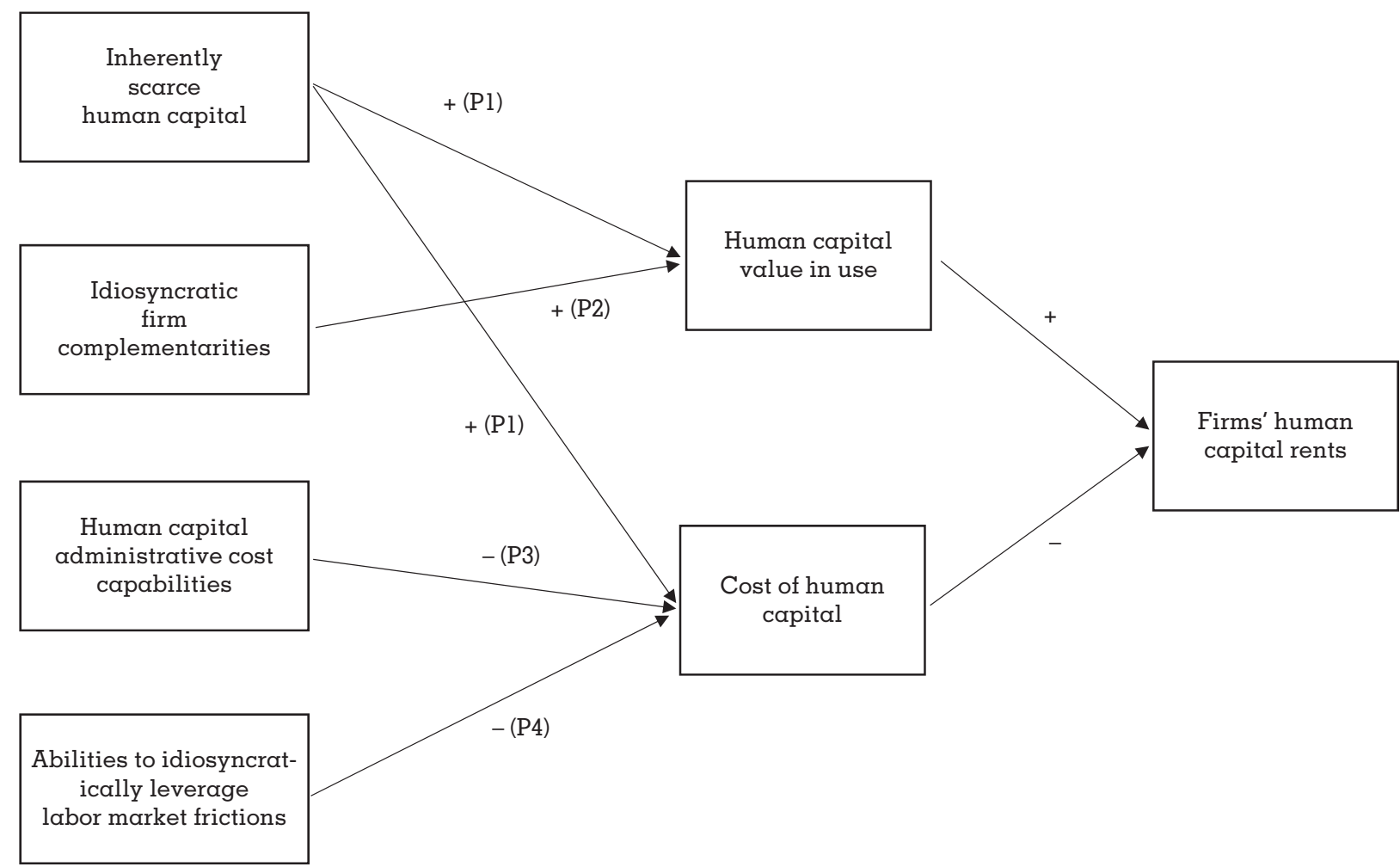

capabilities, and firms' abilities to idiosyncratically leverage labor market frictions decrease firms' cost of human capital. Additionally, although it is not depicted in Figure 2, generically valuable human capital can increase both human capital value in use and firms' cost of human capital, as I describe below.

\section{Inherently Scarce Human Capital}

In formulating human capital theory, Becker and other labor economists were influenced by the kinds of worker skills that were typically matched to wages in labor economic modelsnamely, such explicitly identifiable compensable factors as education, credentials, work experience, and job tenure. These factors reflect skills that can be developed by workers. Yet if workers' firm-specific skills are deemed by their employers to be obsolete, their personal investments in these skills can ultimately be worthless. Thus, a recurring theme in SHC research is how firms can induce workers to develop the firm-specific skills desired by employers in the the face of potential employer opportunism (e.g., Wang \& Barney, 2006; Wang et al., 2009). One commonly recommended resolution for this dilemma is for employers to extend employment security to workers in exchange for their investments in firm-specific skills. ${ }^{5}$ A more complex issue for human copital and firm rents is imitability. Simply put, if firm-specific human capital such as employee relations skills can be learned, then its scarcity will be hard to maintain in the long term. (Note, for instance, how firmspecific human copital is commonly described in SHC research as the result of firms' and workers' joint "investments." If firm-specific human copital can be created, then its long-term supply is elastic.) This is another potential source of employer opportunism. Both of these sources of employer opportunism increase firms' bargaining power over value in use after workers have

\footnotetext{
${ }^{5}$ Indeed, such logic is the traditional rationale for internal labor markets (Doeringer \& Piore, 1971), but it has also been the implicit (and sometimes explicit) rationale for engaging "core" workers in high-commitment work systems in the strategic HRM literature.
} 
invested in firm-specific skills, but they may motivate workers not to make such investments.

However, workers and firms face a different set of challenges in managing human capital that is an intrinsic (i.e., naturally occurring rather than created) characteristic of individual workers (cf. Ployhart \& Moliterno, 2011). Intrinsic differences between individuals include such characteristics as marketing sense, charisma, and cognitive ability. Because these worker characteristics are intrinsic, their labor market supply is largely tied to the rate at which they naturally appear in the population of workers. Thus, some of this type of human capital may be inherently scarce. A subset of these inherently scarce intrinsic individual characteristics will generate significant value in use. J. Crew CEO Mickey Drexler, for exomple, is well known for his innate sense of casual fashion. Truly charismatic leadership is effective precisely because it is both extremely rare and difficult to teach. Variance in individuals' cognitive ability has been well documented to predict variance in job performance (e.g., Schmidt \& Hunter, 1998), and individuals on the high end of the cognitive ability distribution generally have inherent productivity advantages over most other workers, particularly for knowledge work.

The dilemma for firms seeking rents from inherently scarce human capital is that its scarcity favors workers because this human capital is portable across firms, not salable to firms, and cannot be created. This gives workers with valuable inherently scarce human capital considerable bargaining power over firms with respect to the human capital rents created. Thus, inherently scarce human capital can have a positive relationship with human capital value in use and, at the same time, can also have a positive relationship with firms' cost of human capital. In fact, to the extent that the segment of the labor market for inherently scarce human capital approaches perfect competition, the value in use generated by such human capital should be equaled by worker compensation such that the firm accrues no rents from this human capital.

If they can't appropriate its value in use, why would firms employ inherently scarce human capital? Firms do this because at times they need such human capital's unique functionality, even if they only "break even" on inherently scarce human capital. One such circumstance is when complementarities exist with other workers' human capital, with other firm resources, and so forth, as I discuss below. Another circumstance is when the firm needs certain unique tasks accomplished in order to deliver a fully functional product or service. In such cases inherently scarce human capital is a critical part of the firm's value creation system at the same time that it is not a source of human capital rents for the firm. In fact, the lack of required inherently scarce human capital could lead not only to a reduction in firm rents but also to human capital losses for firms if this lack hampers their ability to meet basic production targets. Such circumstances give firms an incentive to raise worker compensation until the cost of inherently scarce human capital nearly equals its value in use. (These two figures will not perfectly match because the cost of inherently scarce human capital to the firm includes the administrative costs of supporting such human capital, as I describe below.) This logic suggests the following research proposition.

Proposition 1: Inherently scarce human capital increases both human capital value in use and firms' cost of human capital in almost equal amounts.

\section{Idiosyncratic Firm Complementarities}

Another way that human capital can generate higher value in use is through the existence of complementarities with other unique resources and capabilities in the firm (e.g., Mackey et al., 2014; Molloy \& Barney, 2015). Milgrom and Roberts (1992) famously defined complementarities as a condition where doing more of a particular activity increases the returns to another related activity. The complementary resource that has received the most attention in SHC research is coworkers' human capital (cf. Barney, 199l; Crocker \& Eckardt, 2014). For example, lawyers have large amounts of human capital that are particular to themselves, such as legal experience, the ability to argue persuasively, the ability to prepare influential legal briefs, and so forth. However, in some types of legal work, such as business acquisitions, teams of lawyers are needed to handle the volume and complexity of clients' transactions. In this type of work, complementarities with coworkers that are particular to the firm create value for customers that goes beyond a simple aggregation of individual lawyers' abilities. 
SHC researchers have recently given greater attention to this theme, often drawing on social capital theory to suggest that the value in use of workers' human capital can be enhanced by their relationships with coworkers in a particular firm (e.g., Campbell, Saxton, \& Banerjee, 2014). ${ }^{6}$ Further, Ployhart, Nyberg, Reilly, and Maltarich (2014) have argued that human capital complementarities with coworkers' human capital can be idiosyncratic to the firm because they are the complex product of idiosyncratic social, affective, and behavioral processes. Similarly, Groysberg's work on the productivity of stock market analysts (e.g., Groysberg, 2012; Groysberg \& Abrahams, 2006) suggests that human capital value in use has a strong idiosyncratic element because of complementarities with an array of idiosyncratic firm resources, such as coworkers' human capital, the firms' internal and external relationship networks, and organizational cultures. Consequently, star analysts who are poached by competitors are unlikely to generate as much value in use at their new firms as they created at their former firms. This point implies that firms are more likely to see rents from poaching individual workers who have few complementarities with their current firm, both because their current value in use is simpler to ascertain and price appropriately and because such workers' performance is centered in their individual human capital and, thus, more easily transferred to another firm.

As Groysberg's work suggests, SHC scholors have begun to explore how complementarities with a variety of firm resources in addition to coworkers' human capital can enhance value in use (e.g., Mackey et al., 2014). For example, Vomberg, Homburg, and Bornemann (2015) recently examined complementarities between human capital and brand equity. Similarly, the implicit story in most strategic HRM (SHRM) research concerns complementarities between human capital and HRM systems that drive up human capital value in use by, for instance, eliciting greater discretionary effort from workers. Clearly, the variety of potential complementarities between human capital and other, idiosyncratic firm resources is wide. Thus,

\footnotetext{
${ }^{6}$ It is important to note that SHC scholars have often considered workers' relationship networks as a form of individual-level human capital. In contrast, the relationships that I mention here are those available in the firm to workers collectively and, thus, are a firm-level resource.
}

multiple human copital complementarities con be at play in a firm simultaneously. For example, professional football players bring large amounts of individualized human capital to their jobs. However, complementarities with their teams' coaching talent, with other players on the team, with the teams' preferred style of play, with team culture and tradition, with geographic locale, and so forth can add extra value in use to what the players themselves bring to the team. Such orguments suggest the following research proposition.

\section{Proposition 2: Idiosyncratic firm com- plementarities increase human capital value in use.}

In sum, idiosyncratic complementarities are drivers of human capital rents for firms because they increase value in use in ways that cannot be achieved with the same human capital at another firm. Thus, idiosyncratic complementarities give human capital value in use its firm-specific character. Since idiosyncratic complementarities do not occur without their firms' participation in the employment relationship, firms rather than workers have strong claims on the majority of the value in use that such complementarities generate (cf. Mackey et al., 2014). In other words, idiosyncratic complementarities' can increase human capital value in use with relatively small concurrent increases in the cost of human capital. Consequently, firm complementarities are likely to be a key driver of the variance in human capital rents across firms.

However, while firms have a bargaining advantage over the human capital rents that idiosyncratic firm complementarities help to create, if firms drive too hard a bargain over such human capital rents, workers may become disaffected. Therefore, it is likely that firms will pay workers a portion of the value in use created by firms' idiosyncratic resources and capabilities (cf. Molloy \& Barney, 2015). In fact, because engaging workers' free will is so difficult for firms to do, complementorities that successfully encompass an affective dimension may be the complementarities that are especially important in determining cross-firm differences in human capital rents.

\section{Administrative Cost Capabilities in Managing Human Capital}

A factor affecting firms' cost of human capital that has hitherto been largely overlooked in SHC 
scholarship is the role of administrative cost effectiveness in managing human capital. Firms' cost of human capital encompasses both workerspecific compensation and the indirect human capital "infrastructure" costs that firms pay to acquire and retain workers' human capital, including the costs of training programs, employee relations programs, HRM systems, maintenance of the firm's culture, and so forth. This latter type of human capital cost generalizes across groups of workers. Human capital administrative capabilities can help firms capture a larger share of the value that workers' human capital creates by driving down the cost of human capital. However, this process is not value appropriation, which concerns how the value that human capital generates from customers is divided between a worker and the firm. Thus, human capital administrative effectiveness is value capture, even if it is not value appropriation.

Much human capital administrative cost effectiveness pertains to activities that all firms perform. Indeed, some of the most important human capital management practices, such as consistent payroll administration, are common across firms and, thus, are competitively differentiating only when firms perform them poorly. Nevertheless, the impact of such cross-firm differences in human capital administrative efficiencies may be substantial. Chadwick, Ahn, and Kwon (2012), for example, reported that the relative efficiency with which firms manage their human capital can vary markedly and may be a more important driver of differences in firms' financial performance than are HRM practices' effects on firms' revenues. This seems to be particularly true for firms that are very low in relative human capital management efficiency.

SHRM scholars have begun to investigate human capital administrative efficiencies by trying to copture the effectiveness with which HRM practices are administered within firms, although to date this nascent stream of research has not typically distinguished between commonplace and more idiosyncratic HRM practices. Some of firms' most inimitable administrative cost capabilities appeal to workers affectively as well as instrumentally. For example, Nishii, Lepak, and Schneider (2008) documented how employees' attributions regarding managers' motivations in implementing a human capital management practice can profoundly influence the worker behaviors that the practice induces. While the extant evidence is sparse, such work suggests that firm heterogeneity in human capital administrative capabilities can be another contributor to the Ricardian rents that RBT scholars describe. Here again, firms' human capital rents are anchored in their idiosyncratic human capitalrelated capabilities.

\section{Proposition 3: Idiosyncratic human capital administrative cost capabilities decrease firms' cost of human capital.}

\section{Abilities to Idiosyncratically Leverage Labor Market Frictions}

Let us next examine labor market frictions more closely. Frictions concern the value appropriation portion of the value capture process. Economists generally regard frictions as undesirable because they can reduce the efficiency with which markets allocate resources for society. In perfect competition, firm-level differences in resources and capabilities that affect competition are quickly dissipated on strategic factor markets as competitor firms acquire the advantageous factor. Thus, firms in such markets are not expected to generate returns beyond their costs of doing business. In contrast, strategy scholars regard market frictions as potentially desirable from a firm's point of view (Nelson, 1991). Indeed, RBT can be described as a theory of strategic factor market deviations from perfect competition (i.e., frictions) that prevent competitors from quickly acquiring, imitating, or substituting for competitively valuable resources and capabilities (Barney, 1991; Peteraf, 1993). Consequently, the rents generated for firms by these resources and capabilities can be persistent rather than temporary.

More specific to the arguments in this article, labor market frictions can give firms opportunities to appropriate value in use that workers' human capital creates by inhibiting workers' ability to trade on their human capital in the labor market. For instance, a common type of market friction is asymmetric information about product quality, such as when sellers more accurately comprehend the value of their products than do potential purchasers. Other things being equal, human capital information asymmetries depress firms' demand for human capital by making the returns to human capital more difficult to predict (a version of the "market for lemons" phenomenon). Information 
asymmetries regarding human capital are likely to be commonplace because human capital value in use has an idiosyncratic component that is difficult to predict prior to an employment relationship. Note, for instance, that objective measures of human capital, such as education and experience, express workers' value to firms generally rather than with respect to a firm's idiosyncratic conditions.

Accordingly, an idiosyncratic firm capability that resolves information asymmetries regarding the quality of potential workers within the firm's value creation system could increase that firm's human capital-related rents, particularly if the capability cannot be easily replicated by competitors. For example, Chadwick and Dabu (2009) cited corporate internship programs as vehicles for building firms' knowledge about workers' potential idiosyncratic value in use. A particular firm's internship program that runs more effectively than those of its competitors can enhance human capital rents because this firm may be better able to identify valuable human capital and secure it at a wage that ensures human capital rents for the firm. Indeed, a key human capital management capability may be the ability to identify valuable, inherently scarce human capital more effectively than competitor firms (Chadwick \& Dabu, 2009). This approach harks back to Makadok's (2001) distinction between resource-picking and capability-building approaches to resource-based competitive advantage. The former, resource picking, appears to be Nike's approach to nurturing promising athletes at the beginning of their careers as future celebrity endorsers of its products, for example.

Because it is particularly difficult for firms to engage workers' free will, firms' capabilities related to the affective side of employment relationships may offer especially fruitful opportunities for them to leverage labor market frictions in ways that differentiate them from competitors. For example, workers who feel normative commitment to a firm may be willing to forgo opportunities to sell their services on the labor market in order to further the firm's mission. One of the chief advantages of commitment-based work systems, for instance, is that they create a climate of reciprocal social exchange between the firm and workers that encourages them to continue that relationship, even if it is somewhat economically disadvantageous to do so (Bowen \& Ostroff, 2004). Moreover, capabilities that engage workers affectively are especially difficult for competitors to copy.

Similarly, idiosyncratic abilities to advantageously negotiate with workers over their wage rates may give a firm greater human capital rents. The foct that workers retain perpetual ownership of their human capital lends importance to the effort to leverage labor market frictions to drive down the cost of human capital, since firms' de facto bargaining over worker compensation is correspondingly (if intermittently) perpetual. In terms of Figure 2, other things being equal, labor market frictions enable firms to capture greater rents by driving down the cost they pay to acquire and retain human capital. This logic suggests the following theoretic proposition.

Proposition 4: Capabilities that allow firms to idiosyncratically leverage labor market frictions decrease their cost of human capital.

Since a firm's cost of worker compensation includes both the general market rate for the human capital in question and worker compensation for idiosyncratic firm conditions, we can refine this general argument by distinguishing between labor market frictions' effects on these two components - that is, some labor market frictions may relate primarily to the general market rate for human capital, whereas other labor market frictions may primarily pertain to compensation for idiosyncratic firm conditions. Coupled with Campbell et al.'s (2012) prior distinction between demand-side and supply-side labor market frictions, this point suggests that the labor market frictions that are relevant to firm rents are of four types: (1) demand-side frictions that affect general market rates for human capital, (2) supply-side frictions that affect general market rates for human capital, (3) demand-side frictions that affect worker compensation for idiosyncratic firm conditions, and (4) supply-side frictions that affect worker compensation for idiosyncratic firm conditions.

Accordingly, each of these four types of labor market frictions offers a firm different ways to reduce its cost of human capital, thus increasing its human capital rents. For example, a firm could leverage demand-side frictions that affect human capital market rates if it could negotiate for itself an exception to a government regulation that makes hiring a particular kind of worker less desirable. An example of a supply-side friction that 
affects human capital market rates is when a firm is branded as a preferred employer among the pool of potential employees, thus giving it on advantage over other firms in appealing to potential workers. Rivera (2012), for instance, demonstrated that elite professional service firms can have preferential access to human capital to the degree they match workers on lifestyle markers such as leisure pursuits and presentation styles. A demand-side friction with respect to worker compensation for idiosyncratic conditions is an effective internship program that resolves information asymmetries regarding potential workers' value in use at a particular firm, as I discussed above. Finally, a supply-side friction that influences worker compensation for idiosyncratic conditions in favor of the firm is a clause in professional athletes' labor arrangements preventing rookie players from freely shopping their services to teams in the league. If a rookie becomes a good performer early in her career, her team appropriates value in use from her, some of which is particular to that team, until the player achieves free agency. Thus, distinguishing between these types of labor market frictions more precisely allows us to specify how firms can leverage labor market frictions in greater detail.

\section{Generic Human Capital}

Another factor that can influence human capital rents is generic human capital, such as workers' basic math, accounting, and managerial competencies. This kind of human capital is generic in that it is either intrinsically commonplace in workers or easily acquired by workers when needed. In either case, such human capital is not scarce because its supply is either inherently abundant or readily expandable. ${ }^{7}$ Thus, when firms face a shortage of generic human capital that temporarily drives up the cost of worker compensation, more workers with the requisite generic human capital enter the labor market and quickly drive the market wage back down. This dynamic puts a ceiling on the cost of

\footnotetext{
${ }^{7}$ This concept has some similarity to the more familiar concept of portable (general) human capital from human capital theory, yet in keeping with this article's theoretic orientation, the emphasis here is on scarcity per RBT/strategic factor markets theory rather than on whether the human capital is applicable across firms. Indeed, some portable human capital is for from generic.
}

generic human capital for firms. Consequently, rents for workers from generic human capital are usually trivial.

Because such human capital is commonplace, its basic functions in firms' value creation systems tend to be easily replicated across competitors. This drives the value in use for generic human capital downward toward its cost to firms, narrowing human capital rents for firms as well as for workers. In fact, the impact of generic human capital on value creation may be largest in those cases where, for some reason, required generic human capital is lacking. For example, basic computer support services may not differentiate a firm by creating idiosyncratic value, but if the firm does not have enough workers to perform this function, some of the firm's cost effectiveness will be lost (cf. Porter, 1996).

In terms of Figure 1, this reasoning suggests that generic human capital value in use approximates the cost of generic human capital. Simultaneously, the cost of worker compensation for generic human capital approximates its next best use. Thus, opportunities for human capital rents for either party, firms or workers, are small with respect to general human capital. An exception to this dynamic that may lead to firm rents is, as I discussed previously, when a firm can reduce its human capital administrative costs in ways that competitors cannot replicate, leading to a human capital cost advantage for the firm. In fact, since the gap between value in use and the cost of worker compensation is norrow with generic human capital, if the firm is not operationally effective in administering generic human capital, it may easily realize losses rather than rents from generic human capital. Consequently, idiosyncratic human capital administrative competencies are a key determinant of firm losses from generic human capital.

Proposition 5: Firms' idiosyncratic capabilities to efficiently administer human capital affect whether they realize human capital losses from generic human capital.

The other ways that generic human capital can create rents for firms are connected to the other idiosyncratic firm capabilities I discussed previously-namely, the abilities to leverage labor market frictions or to create complementarities. Specifically, the capabilities to leverage labor market frictions can amplify the somewhat 
negative relationship between generic human capital and the cost of human copital, while the capabilities to create firm complementarities can enhance the somewhat positive relationship that exists between generic human capital and value in use. In a sense, firms can use labor market frictions or complementarities to make generic human capital either less easily tradable on the labor market or less generic in creating value, respectively, and, thus, they can increase their opportunities to garner rents from generic human capital. For example, Chadwick and Dabu (2009) noted how generic human capital can be enhanced by cospecialization with organizational capital and other types of resources with which it interacts within a firm's capabilities (cf. Coff \& Kryscynski, 2011). Further, if a firm can lock in a supply of generic human capital, say, by holding its workers to noncompete agreements that limit their mobility from firm to firm, the firm may be able to drive down the costs that it pays for this human capital to open a larger gap with its value in use.

To cite another example, labor market frictions may explain why, contrary to the received firmspecific human capital theory argument, empirical evidence suggests that firms generally garner sizable positive returns from investments in general skills training (e.g., Bartel, 2000). For instance, some workers may be willing to forfeit some of the value their increased general skills create if their firms are able to increase the affective and financial costs of switching employers. Additionally, workers who receive general skills training may forgo capturing all of the increased value in use of their general human capital because firms' training investments engender feelings of reciprocity that appeal to workers affectively (Baron \& Kreps, 1999)- that is, because firms have engaged workers' free will. This dynamic may induce workers to remain with a firm for compensation that lies below the compensation available at their human capital's next best use. This logic suggests the following research proposition, complementing Proposition 5.

Proposition 6: Firms' idiosyncratic capabilities to leverage labor market frictions or to create complementarities with generic human capital determine whether they realize human capital rents from generic human capital.

In sum, I posit that absent the effects of idiosyncratic firm capabilities to efficiently administer human capital, to leverage labor market frictions, or to create idiosyncratic firm complementarities, generic human capital is unlikely to generate more than very small rents for firms. This point has potentially far-reaching implications for a number of research streams. For example, this discussion puts a finer point on the voluminous findings regarding HRM systems and firm performance that have emerged from the SHRM literature (e.g., Combs, Liu, Hall, \& Ketchen, 2006; Subramony, 2009). HRM systems that increase the generic human capital of the firm-human capital's ability, motivation, and opportunities to contribute to the firm (the "AMO" model; cf. Lepak, Liao, Chung, \& Horden, 2006)-may drive firm rents if they ore linked to idiosyncratic human capital management capabilities. If the human capital in question is generic ability, motivation, and opportunities to contribute, however, and if the HRM system is also a commonly implemented version of a commitmentbased HRM system (i.e., high-performance work systems; cf. Posthuma, Campion, Masimova, \& Campion, 2013), the chances for human capital rents for the firm (absent advantageous labor market frictions) are slim.

This point can be masked empirically if the emphasis in a study is on predicting firm-level labor productivity rather than on revenues net of costs (which gets closer to rents). This concern about SHRM research has been expressed by a number of observers (e.g., Barney \& Wright, 1998; Macky \& Boxall, 2007). Moreover, it is likely that the human capital rents that accrue to firms from these HRM systems are driven by the customized, idiosyncratic portion of these HRM systems, not by those HRM practices that can be implemented relatively uniformly across firms (cf. Chadwick \& Dabu, 2009; Coff \& Kryscynski, 2011). ${ }^{8}$

\section{DISCUSSION}

A fundamental question addressed in this article concerns why human capital rents would go to firms rather than to the workers whose human capital generates rents. As I mentioned at the

\footnotetext{
${ }^{8}$ Acknowledging our earlier discussion of workers' free will, note that the idiosyncratic portion of HRM systems that drives cross-firm heterogeneity in human capital rents can encompass such factors as the climate of the labor-management relationship in addition to the technical effects of the HRM practices.
} 
beginning of the article, the majority of the SHC literature to this point has, either implicitly or explicitly, made it seem as if firms' human capital rents are a function of the human capital itself. As I argue in this article, human capital rents for firms emerge from firms' idiosyncratic resources and capabilities. One might argue that this is the case for firm rents from any type of resource, not just human capital, but the dynamics play out differently with respect to human capital than they do for other resources, particularly because workers have perpetual ownership of their human capital and because firms must appeal to workers' free will both cognitively and affectively. For instance, a critical challenge in achieving rents from inherently scarce human capital is that firms can never buy such human capital from workers. Instead, firms need to continuously engage workers who have needed and inherently scarce human capital in order to retain its services in generating rents. Even in the case of firmspecific human capital, firms' capture of rents from such human capital stems from idiosyncratic firm capabilities, such as the ability to induce workers to make firm-specific human capital investments.

As I mentioned at the beginning of the article, the SHC research conversation has been broadened significantly in recent years. A number of new themes have grown out of this discussion, including labor market frictions, human capital management capabilities, inherent versus created human capital, human copital scorcity, firms' human capital complementarities, the strategic value of HRM practices, and so forth. This article weaves these disparate themes together into a more comprehensive view of firm-level human capital rents. For example, many of the arguments to date in the SHC literature have emphasized how value is appropriated between firms and workers (e.g., Campbell et al., 2012), which itself is a complex subject. Yet a related key topic is human capital value creation (e.g., Molloy \& Barney, 2015; Ployhart et al., 2014). Together, an eye toward both value capture and value creation gives a fuller view of firms' human capital rents. Moreover, as I discussed above, the factors that drive value creation and value capture can differ significantly, particularly in specific contingencies, and this article has worked to more fully map those theoretic relationships. In doing so I have endeavored to anchor the SHC literature more firmly to the RBT/strategic factor markets perspective, to which it so frequently bears homage.

For instance, while Campbell et al.'s (2012) article is persuasive and important, it is still difficult to predict whether firms will garner human capital rents in a majority of the circumstances that the authors outline. Specifically, in Campbell et al.'s framework, when supply-side and demand-side labor market frictions are mixed between high and low states, firms' human capital rents are uncertain. Thus, while Campbell et al. open the door to a wider consideration of the labor market frictions that allow firms to appropriate human capital rents, human capital value creation has not heretofore received as comprehensive a revision. Moreover, the issue of human capital administrative capabilities is not part of these authors' value capture framework.

In other words, this article's major contribution to SHC research lies in integrating different human capital-related constructs and proposing their basic interrelationships. In general, on the one hand, the cost of human capital is related to ownership-based bargaining power, with such factors as inherently scarce human capital and nonfinancial compensation increasing or decreasing that bargaining power for workers and firms. On the other hand, labor market frictions generally may modify human capital scarcity to firms' advantage. Other factors such as inherently scarce human capital and firm complementarities have direct relationships with value in use.

The arguments in this article also suggest some points that are new to the SHC literature, such as the importance of firms' administrative effectiveness in managing human capital. Such effectiveness can lead to greater value capture for firms, but it is also possible that value capture can be hindered by human capital administrative inefficiencies. When the gap between value in use and the cost of worker compensation is very narrow (such as with generic human capital), it is even possible that human capital administrative inefficiencies may generate human capital losses. Typically, SHC research focuses on factors that affect the size of the gap between value in use and the cost of human capital, but the idea that this gap could be turned into losses is a point that is rarely acknowledged in the extant literature.

Moreover, I have suggested that the factors that influence value in use and the cost of human capital can have significant interrelationships 
with respect to human capital rents (for clarity, these interrelationships are not represented in Figure 2). For example, a firm's ability to leverage labor market frictions may lessen the bargaining power of workers over the value in use created by their inherently scarce human capital. In such ways these interrelationships suggest boundary conditions that the key constructs in this article's arguments impose on each other with respect to firms' human capital rents (cf. Armstrong \& Shimizu, 2007). This topic is a rich opportunity for future research, since other interrelationships between key constructs, beyond those discussed in this article, are likely to exist.

\section{Implications for Strategic Choice and Managerial Human Capital}

Additionally, the relationships outlined in this article pose intriguing questions with respect to firms' strategic choices. Traditional RBT is agnostic about managerial action, since this theory emphasizes the consequences and perpetuation of firm-level heterogeneity rather than its origins. Strategy scholars have begun extending RBT to address this topic under the resource orchestration label (e.g., Helfat, 2007; Sirmon, Hitt, Ireland, \& Gilbert, 2011). The essential argument in resource orchestration is that managers' abilities and choices in bringing resources to bear on strategic issues are one of the most important long-term drivers of firm rents, a view that is consistent with the arguments in this article. For example, in some circumstances it may be more fruitful for a firm to invest in capabilities that create human capital complementarities and to minimize its requirements for inherently scarce human capital by deskilling jobs. In other instances it may be valuable for a firm to identify inherently rare human capital more effectively than competitors, allowing it to acquire that human capital at a discount relative to its potential value in use.

In fact, it is possible to extend this argument: if firms' human capital rents are primarily driven by their human capital-related capabilities, then how firms purposely create and manage those capabilities is, perhaps, the key strategic question in SHC research. For example, all else being equal, value in use is the ceiling of the cost that rational firms will pay for any type of human capital, but this value may not always be apparent prior to the start of an employment relationship. This can be particularly true when complex complementarities within groups of workers make it difficult to determine how much value in use can be tied to individuals. Thus, a specific human capital management capability regarding labor market frictions is the ability to accurately determine the future value in use of a worker's human capital. More generally, this point suggests that firm-level resources and capabilities are the critical unit of analysis for predicting firms' human capital rents.

Firms' human capital-related capabilities rely, in turn, on human capital and other firm resources that reside in those human capital-related capabilities. Thus, the human capital that is embedded in firms' human capital-related capabilities may be, in the end, the human capital that is most vital to firms' human capital rents. This human capital can reside in many different workers, including HR professionals, line managers, and even nonmanagerial workers (cf. Chadwick \& Dabu, 2009). Accordingly, how firms' human capital-related capabilities originate and work in practice is a compelling topic for future research. For instance, this topic adds a strategic flavor to SHRM concerns about the value of in-house HRM departments (e.g., Welbourne \& Cyr, 1999). This article's framework suggests that an in-house HRM department can be strategically valuable when it helps its firm leverage labor market frictions or reduce administrative human capital costs more effectively than other firms, allowing the firm to reap greater rents by driving down the cost of human capital. Moreover, HRM departments can increase value in use when they enhance their firms' abilities to generate complementarities between human capital and other firm resources. When an in-house HRM department does not perform these functions, HRM within the firm becomes primarily on efficiency concern that is vulnerable to cost-based outsourcing in order to prevent human capital losses stemming from administrative inefficiencies. Nevertheless, even administrative HRM can enhance human capital rents if the firm is able to create administrative capabilities that are scarce, inimitable, and nonsubstitutable.

This article's perspectives may also offer avenues for bringing together the depictions of top management strategic decision making in the resource orchestration and upper echelons streams of research. Resource orchestration research describes how upper managers marshal resources and coordinate the efforts of workers and 
managers in the firm around strategic initiatives (e.g., Sirmon et al., 2011). Upper echelons research emphasizes how upper-level managers' instinctive approaches to strategic decision making influence which strategic phenomena capture their interest and the strategic choices that managers make about these phenomena. Human capital management may be one domain where both explanations of managers' strategic decision making-conscious resource orchestration and intuitive, default approaches to strategic decisions-may have explanatory power. Firms do, indeed, regularly make conscious human capital management decisions, but their decisions are also strongly influenced by top managers' implicit theories about how to manage people strategically. For example, Baron, Burton, and Hannan (1996) found that Silicon Valley IPO firms were imprinted with their entrepreneurial founders' values, many of which reflected the founders' personalities and life experiences in addition to conscious strategic calculation, and that these values had long-lasting effects on their firms' approaches to managing their human capital.

\section{Opportunities for Future Research}

No other type of resource has free will, but many of the dynamics outlined here may take place when ownership of an important resource is divided between two or more parties and cannot be resolved by simple purchase. For example, when a restaurant chain franchises, both parties-the chain and franchisees-control important assets that give them bargaining power over the value created by those assets. Strategic factor market frictions, idiosyncratic firm complementarities, and inherent scarcity favoring one party over the other can influence the distribution of value in use in these cases, too. Thus, despite human capital's unique complexity, the $\mathrm{SHC}$ research stream, as it evolves, may inform our understanding of firm rents from other types of resources.

Additionally, the arguments in this article draw stronger connections with the underlying economics of human capital in ways that have been obscured by the field's emphasis on classic human capital theory, which, ironically, originated in labor economics. Strategic factor market theory and RBT apply economic reasoning. Thus, there are unexplored intersections between labor economic models of optimal employment based on marginal revenues and costs and the RBT-based arguments about expanding firms' human capital rents that are encapsulated in Figure 1. One difference between the two streams of research is that this article's conceptual logic builds from the firm level to (implicitly) competitive interactions in populations of firms, while labor economists tend to work down from the broad markets to the decisions that firms make. Nevertheless, there is an interesting opportunity for SHC scholars to broaden ourselves conceptually by building a bridge to labor economics. ${ }^{9}$ This is particularly true with respect to labor market frictions, a topic with which labor economists are very familiar.

Another question for future research concerns the functional forms of human capital complementarities. The current nascent stream of research on human capital complementarities in SHC is mostly concerned with documenting that complementarities exist and, secondarily, with cataloging the different types of constructs that can create complementarities with human capital. Yet Ennen and Richter (2010), among other observers, have noted that the functional form of complementarities can vary significantly in ways that affect the returns to those interactions. How firms should structure complementarities with human capital in order to maximize rents is as yet a largely unexplored topic.

Similarly, the corporate governance structures that are most amenable to human capital complementarities (and the other factors that drive human capital rents in Figure 2) are still ambiguous. Workers' human capital can be acquired under a variety of employment modes, running the continuum from full incorporation within the firm's management structure to spot market exchanges where workers provide a specific temporary service to the firm. This issue bears on the larger question of what a firm is or, perhaps more precisely, whom a firm is. How much must workers be in or out of a firm for the firm to garner human capital rents? Must, for instance, workers with inherently scarce human capital be located within the firm's hierarchy for it to capture the rents so generated? The way forward here may involve an intersection between transaction costs economics, which emphasizes a continuum of governance structures, and the SHRM literature, which has a tradition of examining different

\footnotetext{
${ }^{9}$ I thank an anonymous $A M R$ reviewer for suggesting this point.
} 
employment relationships for different groups of workers.

Indeed, this article's discussion of human capital scarcity and value in use evokes an influential theoretic framework in the SHRM stream of research found in Lepak and Snell (1999). These authors proposed optimal employment modes for different combinations of value in use and firm specificity. For example, they posited that when human capital is low in both value in use and firm specificity, the rent-maximizing approach is transactional, emphasizing spot market contracting in human capital acquisition and compliance commitment in human capital management. The perspectives in this article put a finer point on Lepak and Snell's arguments. The authors' definition of value in use (1999: 35) contrasts returns ("strategic benefits to customers") from human capital with the costs incurred for that human capital, as I do here. However, the distinction between value creation and value capture does not appear in Lepak and Snell's framework. Rather, value in use is assumed to be either high or low exogenously, when, in fact, it is an endogenous reflection of both inherent human capital characteristics and factors under firms' control, such as complementarities. Additionally, Lepak and Snell focused the other axis of their framework on human capital firm specificity. As I discussed above, firm specificity gives a limited view of value capture with respect to human capital rents, since labor market frictions of many types can increase human capital scarcity.

Nevertheless, Lepak and Snell's (1999) insights and those that others have subsequently built in SHRM research can help point the way toward the employment modes that firms could use to govern their pursuit of human capital rents, a topic that deserves greater development in SHC research. For instance, one theme in SHRM research is the importance of structuring workforces to be able to extend guarantees of employment stability to workers with highly valued human capital. SHRM scholars have emphasized that a way to credibly make such guarantees to "core" workers is to use another set of "peripheral" workers with temporary employment contracts to buffer the firm's workforce from fluctuations in product market demand, an intriguing proposition that has yet to be explored in SHC research.

An additional opportunity suggested by my arguments in this article lies in expanding the types of workers highlighted in SHC research. Despite recent attention given to middle managers and other lower-level workers (e.g., Wooldridge, Schmid, \& Floyd, 2008), it is traditional in the strategy field to emphasize top-level managers, such as CEOs, COOs, functional heads, and board members, as the workers whose actions most influence firm performance (e.g., Mackey، 2008). SHC scholars have shown an analogous propensity to favor various kinds of "star" workers with clearly critical human capital, such as lawyers, investment analysts, and professional athletes. They have had less to say about how to manage the human capital of other types of workers, such as temps, clerks, receptionists, maintenance workers, and so forth. This article's framework suggests how firms can pursue human capital rents from a variety of workers, not just those whose human capital is inherently scarce and valuable, and, thus, it can help expand the SHC conversation.

A further opportunity to expand this article's reasoning concerns other types of human capital in addition to generic and inherently scarce human capital. These two types of human capital represent ends of a continuum with respect to human capital's intrinsic scarcity. It is possible that other key attributes of human capital can be used to generate a broader typology of human capital that is pertinent to human capital rents, which would enhance the story told in this article, particularly about the ways human capital generates value in use. To date, SHC scholars have been more successful in describing value capture than how human capital value creation works. Perhaps more fully defining how various types of human capital differ is a way to begin to redress that imbalance.

An intriguing example of such opportunities lies in Molloy and Barney's (2015) article. The authors contrast general human capital with three different kinds of firm-specific human capitalrequired, discretionary, and cospecialized firmspecific human capital. They interact these different types of human capital with variance in labor market competitiveness to determine how value in use is split between workers and firms. The authors' general point that human capital value appropriation occurs in the context of labor market conditions is consistent with my arguments here. It would be intriguing to push past this point to detail how value creation also differs in its essential characteristics across conditions both internal and external to the firm, such as 
when the firm is utilizing stocks of inherently scarce human capital or other types of human capital not yet explicitly treated in the SHC literature.

Indeed, another opportunity for future research lies in elaborating the microfoundations of human capital value in use and the cost of human capital. A "deep dive" of this sort would be a more detailed description of interactions between workers and more specifically delineated human capitalrelated capabilities, something that is beyond the scope of this article. For instance, HRM scholars have suggested that realistic job previews can increase the possibility of making productive matches between workers and firms by allowing workers to bring their proprietary knowledge of their copabilities into the recruiting and selection process. Realistic job previews may be a more strategically valuable tool when the costs of a mismatch between firms and workers are particularly high and when information asymmetries regarding human capital's potential value in use are especially acute. Realistic job previews may also be more useful in acquiring inherently scarce human capital than they are for jobs where firm complementarities with generic human capital are the primary driver of human capital rents. Perhaps the most important area for SHC microfoundational work lies in specifying how individual workers' interactions with firms lead to the firmlevel relationships between constructs that I have described. As other SHC scholars have forcefully argued, firm-level SHC relationships are not simple additive aggregations of a series of individuallevel interactions (e.g., Ployhart \& Moliterno, 2011). Specifying microfoundations such as these therefore offers considerable potential to enrich the SHC research conversation (cf. Coff \& Kryscynski, 2011; Ployhart et al., 2014).

As I suggested at the beginning of the article, these explorations will be more fruitful when they acknowledge workers' free will and their perpetual ownership of their human capital. Both of these dimensions certainly add complexity to the human capital rents story. For instance, in addition to its influence on human capital value creation, free will impacts the bargaining that occurs between workers and firms over human capital value in use. Since employment is on affective relationship as well as a labor economic exchange (Wang et al., 2009), firms' approaches to bargaining with workers need to acknowledge both of these facets (such as, for instance, attending to both procedural justice and distributive justice). This makes such bargaining complex and prone to missteps on the part of the firm. Therefore, the ability to effectively bargain with workers may be yet another human capital-related capability of firms that drives differences in human capital rents. As I noted earlier, no other class of resources that firms use is subject to both perpetual ownership and free will, attributes that make firms' pursuit of human capital rents both different and more hazordous than seeking rents through other types of firm resources. In general, the notion that workers' utility functions encompass other outcomes such as fulfilling work, employment stability, and relationships with coworkers offers rich opportunities to sketch out human capital rents' microfoundations more completely (cf. Molloy \& Barney, 2015).

\section{CONCLUSION}

This article has described a number of potential avenues that firms could take to create and secure human capital rents. These avenues leverage idiosyncratic firm capabilities and resources to enhance value in use and to decrease firms' cost of human copital. The two processes that determine value in use and the cost of human capital (human capital value creation and value copture) are distinct but interrelated, and together they determine the extent to which firms garner human copital rents. As strategy researchers have emphasized for some time, firms' rents are rooted in the distinctive capabilities and unique resources that firms bring to the competitive arena. With respect to human capital, firms' options to accrue rents are for broader than commonly acknowledged to date.

\section{REFERENCES}

Armstrong, C. E., \& Shimizu, K. 2007. A review of approaches to empirical research on the resource-based view of the firm. Journal of Management, 33: 959-986.

Barney, J. 1991. Firm resources and sustained competitive advantage. Journal of Management, 17: 99-120.

Barney, J. B., \& Wright, P. M. 1998. On becoming a strategic partner: The role of human resources in gaining competitive advantage. Human Resource Management, 37: 31-46.

Baron, J. N., Burton, M. D., \& Hannan, M. T. 1996. The road taken: Origins and evolution of employment systems in emerging companies. Industrial and Corporate Change, 5: 239-275.

Baron, J. N., \& Kreps, D. M. 1999. Strategic human resources: Frameworks for general managers. New York: Wiley. 
Bartel, A. P. 2000. Measuring the employer's return on investments in training: Evidence from the literature. Industrial Relations, 39: 502-524.

Becker, G. S. 1962. Investment in human capital: A theoretical analysis. Journal of Political Economy, 70(5): 9-49.

Becker, G. S. 1964. Human capital. New York: Columbia University Press.

Bowen, D. E., \& Ostroff, C. 2004. Understanding HRM-firm performance linkages: The role of the "strength" of the HRM system. Academy of Management Review, 29: 203-221.

Campbell, B. A., Coff, R., \& Kryscynski, D. 2012. Rethinking competitive advantage from human capital. Academy of Management Review, 37: 376-395.

Campbell, B. A., Saxton, B. M., \& Banerjee, P. M. 2014. Resetting the shot clock: The effect of co-mobility on human capital. Journal of Management, 40: 531-556.

Chadwick, C., Ahn, J., \& Kwon, K. 2012. Human resource management's effects on firm level relative efficiency. Industrial Relations, 51: 704-730.

Chadwick, C., \& Dabu, A. 2009. Human resources, human resource management, and the competitive advantage of firms: Toward a more comprehensive model of causal linkages. Organization Science, 20: 253-272.

Coff, R., \& Kryscynski, D. 2011. Drilling for micro-foundations of human capital-based competitive advantages. Journal of Management, 37: 1429-1443.

Coff, R. W. 1997. Human assets and management dilemmas: Coping with hazards on the road to resource-based theory. Academy of Management Review, 22: 374-402.

Coff, R. W. 1999. When competitive advantage doesn't lead to performance: The resource-based view and stakeholder bargaining power. Organization Science, 10: 119-133.

Coff, R. W. 2010. The coevolution of rent appropriation and capability development. Strategic Management Journal, 31: 711-733.

Combs, J., Liu, Y., Hall, A., \& Ketchen, D. 2006. How much do high-performance work practices matter? A metaanalysis of their effects on organizational performance. Personnel Psychology, 59: 501-528.

Crocker, A., \& Eckardt, R. 2014. A multilevel investigation of individual- and unit-level human capital complementarities. Journal of Management, 40: 509-530.

Doeringer, P. B., \& Piore, M. J. 1971. Internal labor markets and manpower analysis. New York: D. C. Heath.

Ennen, E., \& Richter, A. 2010. The whole is more than the sum of its parts-or is it? A review of the empirical literature on complementarities in organizations. Journal of Management, 36: 207-233.

Groysberg, B. 2012. Chasing stars: The myth of talent and the portability of performance. Princeton, NJ: Princeton University Press.

Groysberg, B., \& Abrahams, R. 2006. Lift outs: How to acquire a highfunctioning team. Harvard Business Review, 84(12): 133-140.

Hart, O., \& Moore, J. 1994. A theory of debt based on the inalienability of human capital. Quarterly Journal of Economics, 109: 841-879.
Hatch, N. W., \& Dyer, J. H. 2004. Human capital and learning as a source of sustainable competitive advantage. Strategic Management Journal, 25: 1155-1178.

Helfat, C. E. 2007. Dynamic capabilities: Understanding strategic change in organizations. New York: Wiley-Blackwell.

Kor, Y. Y., \& Leblebici, H. 2005. How do interdependencies among human-capital deployment, development, and diversification strategies affect firms' financial performance? Strategic Management Journal, 26: 967-985.

Kracijenbrink, J. 2011. Human capital in the resource-based view. In A. Burton-Jones \& J.-C. Spender (Eds.), The Oxford handbook of human capital: 218-237. Oxford: Oxford University Press.

Lepak, D. P., Liao, H., Chung, Y., \& Harden, E. E. 2006. A conceptual review of human resource management systems in strategic human resource management research. Research in Personnel and Human Resources Management, 25: 217-271.

Lepak, D. P., \& Snell, S. A. 1999. The human resource architecture: Toward a theory of human capital allocation and development. Academy of Management Review, 24: 31-48.

Mackey, A. 2008. The effect of CEOs on firm performance. Strategic Management Journal, 29: 1357-1367.

Mackey, A., Molloy, J., \& Morris, S. 2014. Scarce human capital in managerial labor markets. Journal of Management, 40: 399-421.

Macky, K., \& Boxall, P. 2007. The relationship between "highperformance work practices" and employee attitudes: An investigation of additive and interaction effects. International Journal of Human Resource Management, 18: 537-567.

Makadok, R. 2001. Toward a synthesis of the resource-based and dynamic-capability views of rent creation. Strategic Management Journal, 22: 387-401.

Mayer, K. J., Somaya, D., \& Williamson, I. O. 2012. Firmspecific, industry-specific, and occupational human capital and the sourcing of knowledge work. Organization Science, 23: 1311-1329.

Milgrom, P., \& Roberts, J. 1992. Economics, organization, and management. Englewood Cliffs, NJ: Prentice-Hall.

Molloy, J., \& Barney, J. 2015. Who captures the value created with human capital? A market-based view. Academy of Management Perspectives, 29: 309-325.

Nelson, R. R. 1991. Why do firms differ, and how does it matter? Strategic Management Journal, 12: 61-72.

Nishii, L. H., Lepak, D. P., \& Schneider, B. 2008. Employee attributions of the "why" of HR proctices: Their effects on employee attitudes and behaviors, and customer satisfaction. Personnel Psychology, 61: 503-545.

Penrose, E. T. 1995. The theory of the growth of the firm. Oxford: Oxford University Press.

Peteraf, M. A. 1993. The cornerstones of competitive advantage: A resource-based view. Strategic Management Journal, 14: 179-191.

Ployhart, R. E., \& Moliterno, T. P. 2011. Emergence of the human capital resource: A multilevel model. Academy of Management Review, 36: 127-150. 
Ployhart, R. E., Nyberg, A. J., Reilly, G., \& Maltarich, M. A. 2014. Human capital is dead; long live human capital resources! Journal of Management, 40: 371-398.

Porter, M. E. 1996. What is strategy? Harvard Business Review, 74(6): 61-78.

Posthuma, R. A., Campion, M. C., Masimova, M., \& Campion, M. A. 2013. A high performance work practices taxonomy: Integrating the literature and directing future research. Journal of Management, 39: 1184-1220.

Rivera, L. 2012. Hiring as cultural matching: The case of elite professional service firms. American Sociological Review, 77: 999-1022.

Schmidt, F. L., \& Hunter, J. E. 1998. The validity and utility of selection methods in personnel psychology: Practical and theoretical implications of 85 years of research findings. Psychological Bulletin, 124: 262-274.

Sirmon, D. G., Hitt, M. A., Irelond, R. D., \& Gilbert, B. A. 2011. Resource orchestration to create competitive advantage. Journal of Management, 37: 1390-1412.

Subramony, M. 2009. A meta-analytic investigation of the relationship between HRM bundles and firm performance. Human Resource Management, 48: 745-768.

Vomberg, A., Homburg, C., \& Bornemann, T. 2015. Talented people and strong brands: The contribution of human capital and brand equity to firm value. Strategic Management Journal, 36: 2122-2131.

Wang, H. C., \& Barney, J. B. 2006. Employee incentives to make firm-specific investments: Implications for resource-based theories of corporate diversification. Academy of Management Review, 31: 466-476.

Wang, H. C., He, J., \& Mahoney, J. 2009. Firm-specific knowledge resources and competitive advantage: The roles of economicand relationship-based employee governance mechanisms. Strategic Management Journal, 30: 1265-1285.

Welbourne, T. M., \& Cyr, L. A. 1999. The human resource executive effect in initial public offering firms. Academy of Management Journal, 42: 616-629.

Wooldridge, B., Schmid, T., \& Floyd, S. W. 2008. The middle management perspective on strategy process: Contributions, synthesis, and future research. Journal of Management, 34: 1190-1221.

Wright, P. M., Dunford, B. B., \& Snell, S. A. 2001. Human resources and the resource based view of the firm. Journal of Management, 27: 701-721.

Wright, P. M., \& McMahan, G. C. 2011. Exploring human capital: Putting human back into strategic human resource management. Human Resource Management Journal, 21: 93-102.

Clint Chadwick (clint.chadwick@ku.edu) is an associate professor of strategy and human resource management at the University of Kansas. He received his Ph.D. from the Wharton School, University of Pennsylvania. His research interests include the impact of human resource systems, human capital, and human resource departments on firm competitiveness and efficiency. 
Copyright of Academy of Management Review is the property of Academy of Management and its content may not be copied or emailed to multiple sites or posted to a listserv without the copyright holder's express written permission. However, users may print, download, or email articles for individual use. 